\title{
Synthesis, Characterization, and Biological Evaluation of Some 3d-Metal Complexes of Schiff Base Derived from Xipamide Drug
}

\author{
Suman Malik, ${ }^{1}$ Suparna Ghosh, ${ }^{2}$ Bharti Jain, ${ }^{3}$ Archana Singh, ${ }^{1}$ and Mamta Bhattacharya ${ }^{1}$ \\ ${ }^{1}$ Department of Chemistry, Sadhu Vaswani College, Bairagarh, Bhopal 462030, India \\ ${ }^{2}$ Department of Chemistry, Career College, Bhopal 462023, India \\ ${ }^{3}$ Department of Chemistry, Sarojini Naidu Govt. Girls Post Graduate (Autonomous) College, Shivaji Nagar, Bhopal 462003, India
}

Correspondence should be addressed to Suman Malik; drsumanmalik@gmail.com

Received 31 August 2012; Revised 25 October 2012; Accepted 7 November 2012

Academic Editor: Alfonso Castiñeiras

Copyright (C) 2013 Suman Malik et al. This is an open access article distributed under the Creative Commons Attribution License, which permits unrestricted use, distribution, and reproduction in any medium, provided the original work is properly cited.

\begin{abstract}
The present paper deals with the synthesis and characterization of metal complexes of Schiff base derived from xipamide, a diuretic drug. The bidentate ligand is derived from the inserted condensation of 5-aminosulfonyl-4-chloro-N-2,6-dimethyl phenyl2-hydroxybenzamide (Xipamide) with salicylaldehyde in a 1:1 molar ratio. Using this bidentate ligand, complexes of $\mathrm{Hg}$ (II), $\mathrm{Zn}$ (II), and $\mathrm{VO}(\mathrm{IV})$ with general formula $\mathrm{ML}_{2}$ have been synthesized. The synthesized complexes were characterized by several techniques using molar conductance, elemental analysis, magnetic susceptibility, FT-IR spectroscopy, electronic spectra, mass spectra, and particle size analysis. The elemental analysis data suggest the stoichiometry to be $1: 2[\mathrm{M}: \mathrm{L}]$. All the complexes are nonelectrolytic in nature as suggested by molar conductance measurements. Infrared spectral data indicate the coordination between the ligand and the central metal ion through deprotonated phenolic oxygen and azomethine nitrogen atoms. Spectral studies suggest tetrahedral geometry for $\mathrm{Hg}(\mathrm{II}), \mathrm{Zn}(\mathrm{II})$ complexes, and square pyramidal geometry for $\mathrm{VO}(\mathrm{IV})$ complex. The pure drug, synthesized ligand, and metal complexes were screened for their antifungal activities against Aspergillus niger and Aspergillus flavus. The ligand and its $\mathrm{Hg}(\mathrm{II})$ and $\mathrm{VO}(\mathrm{IV})$ complexes were screened for their diuretic activity too.
\end{abstract}

\section{Introduction}

Coordination complexes are gaining importance in recent years especially in the designing of long acting drugs in metabolism. The metal complexes from bidentate ligands have often been studied recently because of their technical applications [1,2] and applications in enhancement of drug action $[3,4]$. Transition metals are essential for normal functioning of living organism and are, therefore, of great interest as potential drugs [5]. The coordination chemistry of nitrogen donor ligands is an active area of research. A great deal of attention in this area has been focused on the complexes formed by $3 \mathrm{~d}$ metals with bidentate ligands using both sulfur and nitrogen $[6,7]$. The Schiff bases are an important class of ligands in coordination chemistry. The study of structural and binding features of various Schiff base complexes can play an important role in better understanding of the complex biological process. Schiff bases derived from salicylaldehyde are well known for their interesting ligational properties and exclusive applications in different fields
[8-10]. It is well known from the literature that Schiff bases derived from thiazide drugs have a strong ability to form metal complexes [11]. The interaction of these donor ligands and metal ions gives complexes of different geometries, and literature survey reveals that these complexes are potentially more biologically active. Thus, in recent years Schiff bases and their metal complexes have attained much attraction because of their extensive biological activities [12, 13]. Keeping the above fact in our mind and in continuation of our earlier work on transition metal complexes with Schiff bases $[14,15]$, the ligand xipamide-salicylaldimine Schiff base (L) has been synthesized. In the present paper, the synthesis and characterization of the ligand and its complexes with $\mathrm{Hg}(\mathrm{II}), \mathrm{Zn}(\mathrm{II})$, and $\mathrm{VO}(\mathrm{IV})$ are being reported.

\section{Experimental}

All the chemicals used were of AR/GR grade and purchased from E-Merck (USA). Chemicals were used without any 
TABLE 1: Analytical data and molar conductance values for ligand and metal complexes.

\begin{tabular}{|c|c|c|c|c|c|c|c|c|c|}
\hline \multirow{2}{*}{ S. number } & \multirow{2}{*}{ Ligand/complexes } & \multicolumn{5}{|c|}{ Elemental analysis (\%): found (Calcd.) } & \multirow{2}{*}{ M.pt. $\left({ }^{\circ} \mathrm{C}\right)$} & \multirow{2}{*}{ Color } & \multirow{2}{*}{$\begin{array}{l}\text { Molar conductance } \\
\Omega^{-1} \mathrm{~cm}^{2} \mathrm{~mol}^{-1}\end{array}$} \\
\hline & & $\mathrm{C}$ & $\mathrm{N}$ & S & $\mathrm{Cl}$ & M & & & \\
\hline 1 & $\mathrm{~L}$ & $56.87(57.57)$ & $5.84(5.96)$ & $6.91(6.97)$ & $7.50(7.61)$ & - & 250 & Peach & - \\
\hline 2 & $\mathrm{HgL}_{2}$ & $47.08(47.32)$ & $4.97(5.01)$ & $5.48(5.73)$ & $6.34(6.36)$ & $17.70(17.98)$ & 241 & Off-White & 13.2 \\
\hline 3 & $\mathrm{ZnL}_{2}$ & $53.48(53.85)$ & $5.64(5.71)$ & $6.38(6.52)$ & $7.01(7.14)$ & $6.51(6.67)$ & 218 & White & 12.8 \\
\hline 4 & $\mathrm{VOL}_{2}$ & $52.87(53.17)$ & $5.79(5.70)$ & $6.67(6.52)$ & $7.09(7.25)$ & $5.27(5.18)$ & 242 & Yellow & 11.8 \\
\hline
\end{tabular}

purification. Xipamide drug was provided by Dishman Pharmaceuticals which was used as such for the synthesis of ligand.

Elemental analyses were carried out on model 240 PerkinElmer elemental analyzer at CDRI, Lucknow. Metal contents were determined gravimetrically using standard methods [16]. Conductivity measurements were made in anhydrous DMF on a Systronics model 305 (India) Conductivity Bridge. Magnetic susceptibility measurements of the complexes in the solid state were determined by vibrating sample magnetometer at Centre for Advance Technology, Indore at room temperature. The electronic spectra of the metal complexes in DMF were recorded on a Perkin-Elmer UV WinLab Spectrophotometer at School of Studies in Chemistry and Biochemistry, Vikram University, Ujjain, India. The infrared spectra of the ligand and complexes were recorded in $\mathrm{KBr}$ pellets using Perkin-Elmer FT-IR spectrophotometer in the range $4000-400 \mathrm{~cm}^{-1}$ at School of Studies in Chemistry and Biochemistry, Vikram University, Ujjain, India. Particle size analysis was carried out at SICART, Gujarat using, laser diffraction particle size analyzer. The instrument used was CILAS 1064L/D model in the range of $0.04-500 \mu \mathrm{m}$. The melting points of the ligand and complexes were recorded in open capillaries on a capillary melting point apparatus.

The antifungal activities of both the ligands and their complexes were tested in vitro for growth inhibitory against Aspergillus niger and Aspergillus flavus by agar growth food poison technique [17] at different concentrations compared with Grisofulvin as appositive control.

The diuretic activity of $\mathrm{Hg}(\mathrm{II})$ and $\mathrm{VO}(\mathrm{IV})$ complexes were tested on white albino mice at Jawaharlal Nehru Cancer Hospital and Research Centre, Bhopal, India. Mice were fed with standard rodent pellet diet and acidified double-distilled water. The selected test compound, ligand, and standard drug xipamide (XM) at a dose of $0.24 \mathrm{mg}$ suspended in $0.5 \%$ gum acacia were administrated to animals of respective group. One group of animal was taken as control. For the measurement of weight of urine, Whatman no. 1 filter paper was used. The urine weight was recorded after two hours.

2.1. Synthesis of the Ligand (Xipamide Salicylaldimine). Equimolar $(0.01 \mathrm{M})$ solutions of pure drug $(0.22 \mathrm{gm})$ and salicylaldehyde $(0.14 \mathrm{~mL})$ were separately dissolved in methanolwater mixture $(1: 1)$ and refluxed for four hours and kept for a day. Peach colour crystals of xipamide Schiff base were formed in the reaction mixture and were filtered and washed thoroughly with 50\% methanol-water mixture, dried

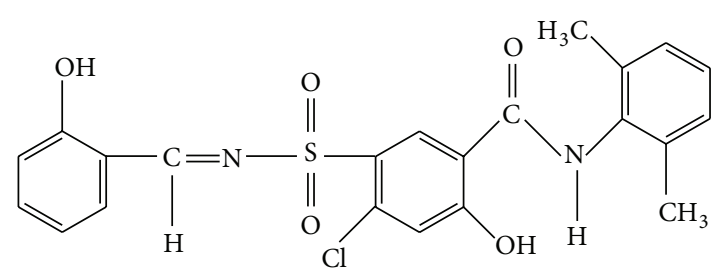

Xipamide-salicylaldimine Schiff base

FIGURE 1: Structure of ligand.

over vacuum, and weighed. Melting point of Schiff base was recorded. The structure of the synthesized ligand is shown in Figure 1.

2.2. Synthesis of Complexes. For the synthesis of complexes, $0.006 \mathrm{M}$ ligand solution was prepared in 50\% acetone-water solvent and refluxed for four hours with $0.003 \mathrm{M}$ solution of metal salts separately. The refluxed solutions were kept for some days. Solid crystalline compounds appeared in the solution, which were filtered, washed with $50 \%$ acetone-water mixture, dried, and weighed. Melting points of the complexes were recorded.

\section{Results and Discussion}

The analytical data of the complexes and their molar conductance values are given in Table 1. All these complexes are analyzed for $1: 2$ stoichiometry of the type $\mathrm{ML}_{2}$. On the basis of these characterizations it has been found that all the complexes are nonhygroscopic, stable at room temperature, insoluble in water, but fairly soluble in DMSO. The molar conductance values of these complexes are too low to account for their electrolytic behavior $[18,19]$.

\subsection{Spectral Studies of Ligand and Its Complexes}

3.1.1. IR Spectra. The characteristic vibrations and assignments of ligand and its complexes are described in Table 2. The IR spectra of the complexes indicate that the ligand behaves as bidentate and coordinates with metals via azomethine nitrogen and phenolic $-\mathrm{OH}$ groups. The shift of $v_{\mathrm{C}=\mathrm{N}}$ to lower wave number by $30-40 \mathrm{~cm}^{-1}$ in the complexes indicates that these groups are involved in complexation $[20,21]$. The ligand shows strong band at $3386 \mathrm{~cm}^{-1}$ due to phenolic -OH group [22]. This band is absent in all the metal complexes indicating the involvement of this group 
TABLE 2: IR spectral data $\left(\mathrm{cm}^{-1}\right)$ of ligand and its complexes.

\begin{tabular}{|c|c|c|c|c|c|c|c|}
\hline S. number & Ligand/complexes & $V_{\mathrm{N}-\mathrm{H}}$ & $v_{\mathrm{C}=\mathrm{N}}$ & $V_{\mathrm{C}-\mathrm{O}}$ & $v_{\mathrm{C}=\mathrm{O}}$ & $v_{\mathrm{M}-\mathrm{N}}$ & $v_{\mathrm{M}-\mathrm{O}}$ \\
\hline 1 & $\mathrm{C}_{22} \mathrm{H}_{19} \mathrm{~N}_{2} \mathrm{O}_{5} \mathrm{ClS}$ & 3302 & 1639 & 1282 & 1671 & - & - \\
\hline 2 & $\mathrm{C}_{44} \mathrm{H}_{36} \mathrm{~N}_{4} \mathrm{O}_{10} \mathrm{Cl}_{2} \mathrm{~S}_{2} \mathrm{Hg}$ & 3301 & 1598 & 1312 & 1669 & 514 & 615 \\
\hline 3 & $\mathrm{C}_{44} \mathrm{H}_{36} \mathrm{~N}_{4} \mathrm{O}_{10} \mathrm{Cl}_{2} \mathrm{~S}_{2} \mathrm{Zn}$ & 3300 & 1623 & 1288 & 1681 & 514 & 580 \\
\hline 4 & $\mathrm{C}_{44} \mathrm{H}_{36} \mathrm{~N}_{4} \mathrm{O}_{10} \mathrm{Cl}_{2} \mathrm{~S}_{2} \mathrm{VO}$ & 3300 & 1620 & 1281 & 1680 & 505 & 608 \\
\hline
\end{tabular}

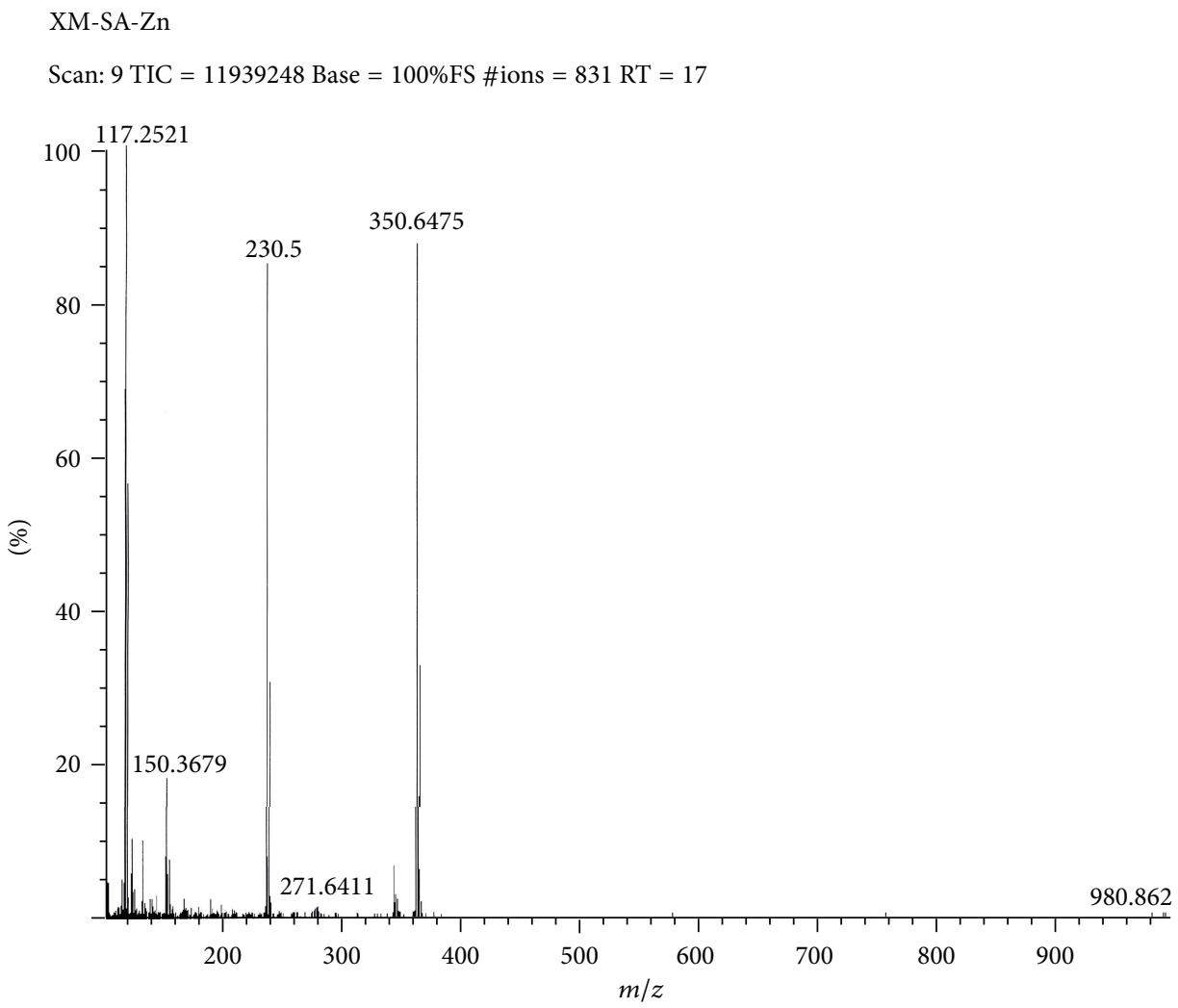

Figure 2: Mass spectrum of $\mathrm{ZnL}_{2}$.

in complex formation [23]. Moreover, the shift of the $v_{\mathrm{C}-\mathrm{O}}$ phenolic bands from $1282 \mathrm{~cm}^{-1}$ in ligand to $1282-1312 \mathrm{~cm}^{-1}$ in the spectra of metal complexes supports the coordination of the phenolic oxygen atom to the metal ion [24]. The bands for $v_{\mathrm{M}-\mathrm{O}}$ modes appeared in the range of $580 \mathrm{~cm}^{-1}-615 \mathrm{~cm}^{-1}$ in all the complexes [25]. The presence of sharp band in the region $503-514 \mathrm{~cm}^{-1}$ in the spectra of all the complexes assigned to $v_{\mathrm{M}-\mathrm{N}}$ mode [26] further support the involvement of azomethine nitrogen atom in coordination. In addition to these bands $\mathrm{VO}(\mathrm{IV})$ complex exhibits the characteristic stretching frequency $[27,28]$ for $\mathrm{V}=\mathrm{O}$ at $952 \mathrm{~cm}^{-1}$.

3.1.2. Magnetic Susceptibility and Electronic Spectra. The magnetic moment obtained for the oxovanadium (IV) complex at room temperature is 1.77 B.M, and its electronic spectra displayed bands at 13986, 17094, and $21740 \mathrm{~cm}^{-1}$ assigned for ${ }^{2} \mathrm{~B}_{2} \rightarrow{ }^{2} \mathrm{E},{ }^{2} \mathrm{~B}_{2} \rightarrow{ }^{2} \mathrm{~B}_{1}$, and ${ }^{2} \mathrm{~B}_{2} \rightarrow{ }^{2} \mathrm{~A}_{1}$ transitions, respectively. These values suggest the square pyramidal geometry for $\mathrm{VO}(\mathrm{IV})$ complex [29]. The $\mathrm{Hg}(\mathrm{II})$ and $\mathrm{Zn}(\mathrm{II})$ complexes are found to be diamagnetic as expected for $\mathrm{d}^{10}$ systems and may have tetrahedral geometry [30].

3.1.3. Mass Spectra. The mass spectrum of $\left[\mathrm{Zn}\left(\mathrm{C}_{22} \mathrm{H}_{18} \mathrm{ClN}_{2}\right.\right.$ $\left.\mathrm{O}_{5} \mathrm{~S}\right)_{2}$ ] as shown in Figure 2 shows a molecular ion peak at $\mathrm{m} / z 980$ (I) due to $\left[\mathrm{Zn}(\mathrm{L})_{2}\right]^{+}$which is in accordance with the proposed formula of the complex. The other peaks at $m / z$ values 151 and 271 may be due to the fragments $\left(\mathrm{C}_{9} \mathrm{H}_{11} \mathrm{NO}\right)^{+}$ and $\left[\mathrm{Zn}\left(\mathrm{ClC}_{6} \mathrm{H}_{4} \mathrm{COH}\right) \mathrm{SO}_{2} \mathrm{NH}\right]^{+}$. The base peak at $\mathrm{m} / z 117$ may be due to the zinc metal linked to the donor atoms of the ligand. Such type of fragmentation pattern has been reported by many workers $[31,32]$.

3.1.4. Particle Size Analysis. To find out the maximum efficiency of the drugs and their metal complexes, studies on the particle size analysis are being considered very helpful [33]. The bioavailability of low-solubility drug is often intrinsically related to the drug particle size. Smaller particle size of the complexes is responsible for the enhanced solubility of the drug [34]. The results of the particle size analysis carried 


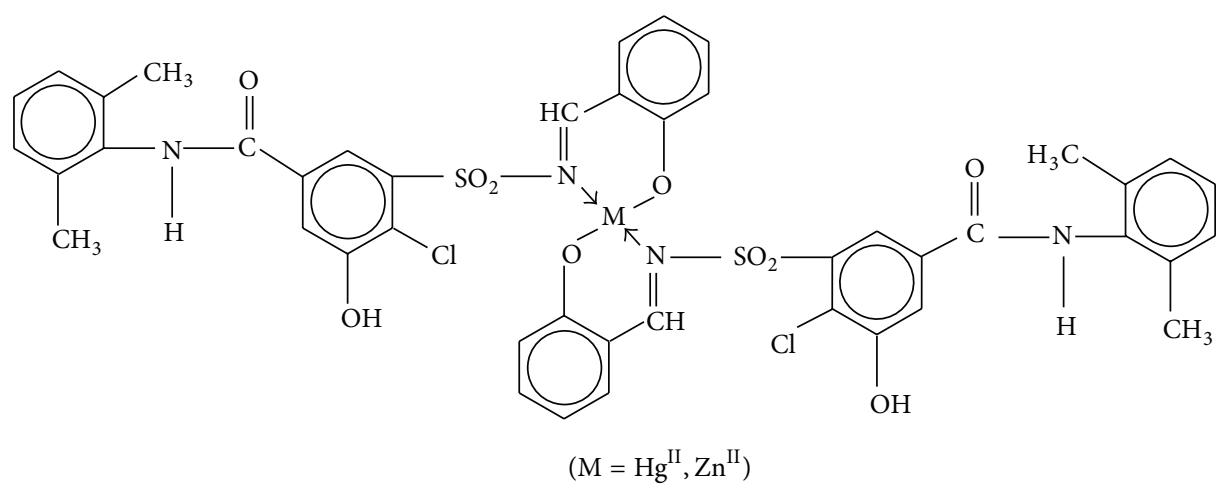

(a)

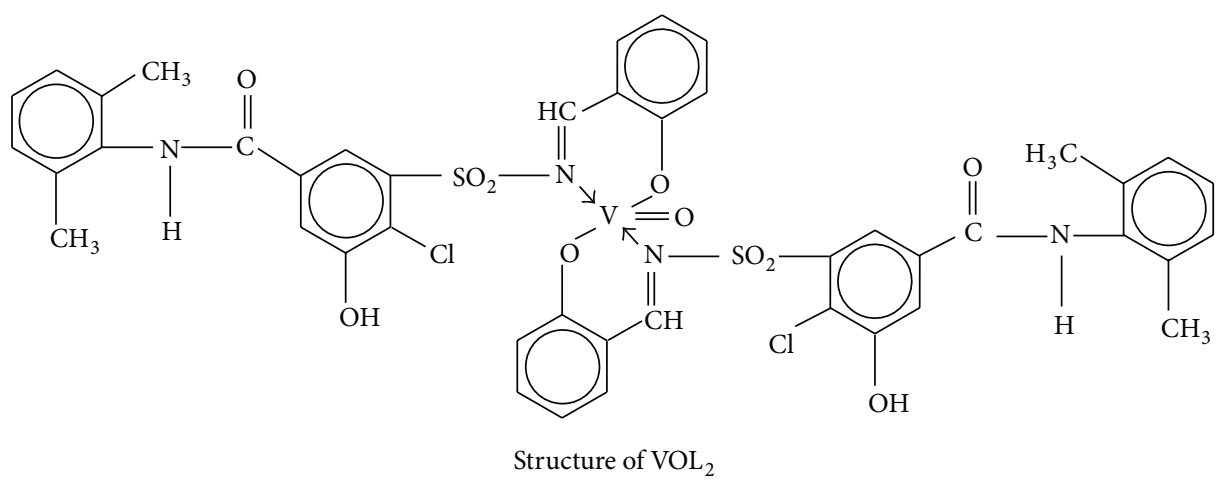

(b)

FIGURE 3: Structure of metal complexes.

TABLE 3: Particle size measurement of pure drug, ligand and its metal complexes.

\begin{tabular}{lcc}
\hline S. number & Sample code & Particle size $(\mu \mathrm{m})$ \\
\hline 1 & $\mathrm{XM}$ & 112 \\
2 & $\mathrm{~L}$ & 95.6 \\
3 & $\mathrm{HgL}_{2}$ & 67.5 \\
4 & $\mathrm{VOL}_{2}$ & 64.5 \\
\hline
\end{tabular}

out for the pure drug, ligand, and its $\mathrm{Hg}$ (II) and $\mathrm{VO}$ (IV) complexes have been recorded in Table 3 . These results reveal that, after complexation, the size of the ligand and complexes got reduced to a considerable extent as compared to their parent drug xipamide (XM). It is well known that smaller size leads to better absorption, so it is concluded from our result that complexation enhanced the absorption and potency of the drug [35].

3.1.5. Antimicrobial Activity. For antifungal activity the ligand and its metal complexes were screened against Aspergillus niger,and the findings are given in Table 4 . These complexes showed higher activity with $12-17 \mathrm{~mm}$ inhibition than the ligand which showed only $11.48 \mathrm{~mm}$ inhibition at the same concentration as that of the test drug. However, ligand
TABLE 4: Antimicrobial screening data of the ligand L and its metal complexes.

\begin{tabular}{lccc}
\hline S. number & $\begin{array}{c}\text { Compound/ } \\
\text { complex }\end{array}$ & $\begin{array}{c}\text { Antifungal zone of inhibition (in mm) } \\
\text { A. niger }\end{array}$ & A. flavous \\
\hline 1 & $\mathrm{~L}$ & 11.48 & 10.38 \\
2 & $\mathrm{HgL}_{2}$ & 15.76 & 16.41 \\
3 & $\mathrm{ZnL}_{2}$ & 13.45 & 14.33 \\
4 & $\mathrm{VOL}_{2}$ & 17.00 & 21.22 \\
5 & Grisofulvin & 19.38 & 18.22 \\
\hline
\end{tabular}

and their complexes showed lower activity as compared to standard drug griseofulvin with $19.38 \mathrm{~mm}$ inhibition at the same concentration.

Antifungal activity studies of ligand and its complexes against Aspergillus flavus showed that all the complexes with $11.47-21.22 \mathrm{~mm}$ inhibition showed higher activity than the ligand which showed only $10.38 \mathrm{~mm}$ inhibition only. VO(IV) complex showed higher activity than standard drug which showed $18.22 \mathrm{~mm}$ inhibition at the same concentration as that of the test drug. It is known that chelation tends to make the ligand act as more powerful and potent antimicrobial agent, thus inhibiting more of the microbes than the parent ligand [36]. 
TABLE 5: Diuretic screening data of the pure drug, ligand, and its metal complexes.

\begin{tabular}{|c|c|c|c|c|c|}
\hline \multirow{2}{*}{ Group } & \multirow{2}{*}{ Ligand/complexes } & \multicolumn{3}{|c|}{ Average volume of urine $(\mu \mathrm{L})$} & \multirow{2}{*}{ Final average $(\mu \mathrm{L})$} \\
\hline & & 1:00 PM & 3:00 PM & 5:00 PM & \\
\hline $\bar{I}$ & Control & 113.94 & 167.22 & 118.01 & $133.06 \pm 29.656$ \\
\hline II & Xipamide & 155.66 & 208.09 & 266.91 & $210.22 \pm 55.656$ \\
\hline III & $\mathrm{L}$ & 175.75 & 235.48 & 289.10 & $233.44 \pm 56.702$ \\
\hline IV & $\mathrm{HgL}_{2}$ & 265.54 & 283.12 & 343.12 & $297.26 \pm 40.6777$ \\
\hline $\mathrm{V}$ & $\mathrm{VOL}_{2}$ & 386.66 & 375.29 & 378.57 & $380.17 \pm 5.852$ \\
\hline
\end{tabular}

3.1.6. Diuretic Activity. The diuretic activity of the $\mathrm{Hg}$ (II) and $\mathrm{VO}(\mathrm{IV})$ complexes was tested on white albino mice and recorded in Table 5. The selected test compound, ligand, and standard drug xipamide at a dose of $0.24 \mathrm{mg}$ suspended in $0.5 \%$ gum acacia were administrated to animals of the respective group. The result revealed that metal complexes have more diuretic activity as compared to the respective ligand and pure drug. Thus it is revealed that complexation can increase the pharmaceutical activity of the parent drug [37].

Statistical analyses were performed by using one-way analysis of variance ANOVA followed by GraphPad InStat 3. Statistical significance was accepted at the $5 \%$ level $(P<0.05)$. The VO(IV) complex is found to be more significant with $P<$ 0.001 whereas $\mathrm{Hg}$ (II) complex is also found to be significant with $P<0.05$.

\section{Conclusion}

The outcome of the above results confirms the stoichiometry of the complexes to be $1: 2[\mathrm{M}: \mathrm{L}]$ as indicated by elemental analysis and conductometric measurements. IR spectra suggest that the ligand behaves as bidentate and coordinates to the central metal ion through azomethine nitrogen and phenolic-OH group. This has been further confirmed on the basis of NMR spectral studies. Mass spectra further support the above stoichiometry on the basis of respective molecular masses and fragmentation patterns. Thus, on the basis of above physicochemical and spectral studies, the assigned structures for the metal complexes are shown in Figures 3(a) and 3(b). The complexes are found to have higher biological activities as compared to the respective ligand and the parent drug that, somehow, justifies the purpose of the research work. The present work will be further extended to the synthesis of metal complexes using other biologically active metals and evaluation of their biological activities.

\section{Acknowledgments}

The authors gratefully acknowledge the financial support provided by UGC. They are also indebted to CDRI, Lucknow, for providing the facilities of elemental analysis, SICART Gujrat for TGA and particle size studies, IIT Chennai for mass spectra, and Vikram University Ujjain for recording IR and electronic spectra. The authors are thankful to Dr. N. Ganesh, Senior Research in Charge and Scientist of Jawaharlal Nehru Cancer Hospital and Research Centre, Bhopal, India, for developing protocol and facilities for diuretic activity.

\section{References}

[1] N. Raman, V. Muthuraj, S. Ravichandran, and A. Kulandaisamy, "Synthesis, characterisation and electrochemical behaviour of $\mathrm{Cu}(\mathrm{II}), \mathrm{Co}(\mathrm{II}), \mathrm{Ni}$ (II) and $\mathrm{Zn}$ (II) complexes derived from acetylacetone and p-anisidine and their antimicrobial activity," Journal of Chemical Sciences, vol. 115, no. 3, pp. 161-167, 2003.

[2] C. Briickner, S. J. Rettig, and D. Dolphin, "2-Pyrrlythiones as monoanionic bidentate N, S- chelators: synthesis and molecular structure of 2-pyrrlythionato complexes of $\mathrm{Ni}(\mathrm{II}), \mathrm{Co}(\mathrm{II})$ and $\mathrm{Hg}$ (II)," Inorganic Chemistry, vol. 39, pp. 6100-6106, 2000.

[3] Y. Prashanthi, K. Kiranmai, Ira. Kumar, S. Chityala, and V. K. Shivraj, "Spectroscopic characterization and biological activity of mixed ligand complexes of $\mathrm{Ni}(\mathrm{II})$ with 1,10-phenanthroline and heterocyclic schiff bases," Bioinorganic Chemistry and Applications, vol. 2012, Article ID 948534, 8 pages, 2012.

[4] N. Raman, S. J. Raja, J. Joseph, A. Sakthivel, and J. D. Raja, "Designing, synthesis, spectral characterization of antimicrobial and DNA active tridentate Schiff base ligands and their complexes," Journal of the Chilean Chemical Society, vol. 53, no. 3, pp. 15991604, 2008.

[5] E. Malhotra, N. K. Kaushik, and H. S. Malhotra, "Synthesis and studies of ionic chelates of hafnocene with guanine," Indian Journal of Chemistry, vol. 45, no. 2, pp. 370-376, 2006.

[6] V. Muresan, L. S. Sbirna, S. Sbirna, C. I. Lepadatu, and N. Muresan, "Transition metal complexes with a new thioamide of the dibenzofuran series," Acta Chimica Slovenica, vol. 48, no. 3, pp. 439-443, 2001.

[7] A. Choudhary, R. Sharma, M. Nagar, and M. Mohsin, "Transition metal complexes with $\mathrm{N}, \mathrm{S}$ donor ligands as synthetic antioxidants: synthesis, characterization and antioxidant activity," Journal of Enzyme Inhibition and Medicinal Chemistry, vol. 26, no. 3, pp. 394-403, 2011.

[8] L. Tatar, D. Ulku, and O. Atakol, "Zinc(II) complexes of bidentate Schiff base ligands containing methoxyphenyl and nitrophenyl groups," Acta Crystallographica C, vol. 55, part 4, pp. 508-510, 1999.

[9] P. Piotr, H. Adam, P. Krystaian, B. Bogemil, and B. Franz, "Biological properties of schiff bases and azo derivatives of phenols," Current Organic Chemistry, vol. 13, no. 2, pp. 124-148, 2009.

[10] F. Shabani, L. A. Saghatforoush, and S. Ghammamy, "Synthesis, characterization and anti-tumour activity of iron(III) Schiff base complexes with unsymmetric tetradentate ligands," Bulletin of the Chemical Society of Ethiopia, vol. 24, no. 2, pp. 193199, 2010.

[11] C. T. Supuran, "Complexes with biologically active ligands. Part 1. Synthesis of coordination compounds of diazoxide with transition- and main-group cations," Metal-Based Drugs, vol. 3, no. 1, pp. 25-30, 1996.

[12] S. Jain, N. K. Jain, and K. S. Pitre, "Electrochemical analysis of sparfloxacin in pharmaceutical formulation and biochemical 
screening of its Co(II) complex," Journal of Pharmaceutical and Biomedical Analysis, vol. 29, no. 5, pp. 795-801, 2002.

[13] S. Chandra, D. Shukla, and L. K. Gupta, "Synthesis and spectroscopic studies of $\mathrm{Co}(\mathrm{II}), \mathrm{Ni}(\mathrm{II})$ and $\mathrm{Cu}(\mathrm{II})$ complexes with $\mathrm{N}$ donor(N4) macrocyclic ligand(DSLF)," Journal of Indian Chemical Society, vol. 85, pp. 800-806, 2008.

[14] S. Malik, S. Ghosh, and L. Mitu, "Complexes of some 3d-metals with a Schiff base derived from 5-acetamido-1,3,4-thiadiazole2-sulphonamide and their biological activity," Journal of the Serbian Chemical Society, vol. 76, no. 10, pp. 1387-1394, 2011.

[15] S. Ghosh, S. Malik, B. Jain, and M. Gupta, "Synthesis, spectral and pharmacological studies of some transition metal complexes derived from Schiff base of Acetazolamide drug," Journal of Indian Chemical Society, vol. 89, pp. 471-478, 2012.

[16] I. Vogel, Quantitative Inorganic Analysis, Longman Green and Co., London, UK, 1959.

[17] V. Kumar and R. Dhakrey, "Synthesis and studies of some metal chelates with phenylglyoxal-4- iminoantipyrine(PGIA) and 4-N-(m-phenoxybenzylidene) amino antipyrine [4-N(MPB)AAP]," Journal of Indian Council of Chemists, vol. 20, no. 1, pp. 61-68, 2003.

[18] W. J. Geary, "The use of conductivity measurements in organic solvents for the characterisation of coordination compounds," Coordination Chemistry Reviews, vol. 7, pp. 81-122, 1971.

[19] B. K. Kumar, V. Ravinder, G. B. Swamy, and S. J. Swamy, "Synthesis and characterization of iron(III), cobalt(II), nickel (II), copper(II), ruthenium(II, III), rhodium(III) and palladium(II) complexes with $\mathrm{N}$-(2-carboxyphenyl)-and 2-amino$\mathrm{N}$-(2-carboxyphenyl)-benzamides," Indian Journal of Chemistry A, vol. 33, pp. 136-142, 1994.

[20] N. Bharti, S. S. Sharma, F. Naqui, and A. Azam, "New palladium(II) complexes of 5-nitrothiophene-2-carboxaldehyde thiosemicarbazones: synthesis, spectral studies and In vitro antiAmoebic activity," Bioorganic \& Medicinal Chemistry, vol. 11, pp. 2923-2929, 2003.

[21] K. Shankar, R. Roshni, K. Saravankumar, P. M. Reddy, and Y. Peng, "Synthesis of tetraaza macrocyclic PdII complexes; antibacterial and catalytic studies," Journal of the Indian Chemical Society, vol. 86, no. 2, pp. 153-161, 2009.

[22] M. L. H. Nair and L. Sharma, "Synthesis,spectral and thermal studies of $\mathrm{Cu}(\mathrm{II})$ complexes of azodyes derived from 2,3dimethyl-1-phenyl-4-amino-5-pyrazolone," Journal of the Indian Chemical Society, vol. 86, no. 2, pp. 133-138, 2009.

[23] V. Reddy, N. Patil, and B. R. Patel, "Synthesis and characterization of $\mathrm{Co}(\mathrm{II}), \mathrm{Ni}(\mathrm{II})$, and $\mathrm{Cu}(\mathrm{II})$ complexes with $\mathrm{O}, \mathrm{N}$ and $\mathrm{S}$ donar ligands," Journal of Indian Council of Chemists, vol. 23, no. 2, pp. 1-3, 2006.

[24] V. D. Bhat and A. Ray, "Synthesis, characterization and electrical conductivity of polyesters, polyamides and doped polymers," Synthetic Metals, vol. 92, pp. 115-120, 1998.

[25] D. Prakash, C. Kumar, S. Prakash, A. K. Gupta, and K. R. R. P. Singh, "Synthesis, spectral characterization and antimicrobial studies of some new binuclear complexes of CuII and NiII Schiff base," Journal of Indian Chemical Society, vol. 86, no. 12, pp. 1257-1261, 2009.

[26] N. Raman, S. Esthar, and C. Thangaraja, "A new Mannich base and its transition metal (II) complexes-synthesis, structural characterization and electrochemical study," Journal of Chemical Sciences, vol. 116, no. 4, pp. 209-213, 2004.

[27] R. Garg, N. Fahmi, and R. V. Singh, "Spectral and biocidal studies of manganese(II), dioxomolybdenum(VI) and oxovanadium $(\mathrm{V})$ complexes with monobasic bidentate Schiff base ligands," Journal of the Indian Chemical Society, vol. 86, pp. 670678, 2009.

[28] S. Z. Bootwala, "Synthesis and characterization of binuclear complexes of oxovanadium (IV), oxozirchonium(IV), dioxouranium(VI) and thorium(IV) with $\mathrm{N}, \mathrm{N}^{\prime}$-bis [(1E,2E)-2(hydroxyimino)-1-phenylethylidene] biphenyl-4,4'-diamine," Asian Journal of Chemistry, vol. 23, no. 12, pp. 5466-5470, 2011.

[29] M. Revanasiddappa, C. Basavarajja, T. Suresh, and S. D. Angadi, "Synthetic, spectral and antimicrobial activity studies of first row transition metal complexes derived from lansoprazole drug," Journal of the Indian Chemical Society, vol. 86, pp. 127132, 2009.

[30] C. A. Barnes and E. Bosch, "Synthesis and X-ray crystal structure of a complex formed by reaction of 1,2-bis $\left(2^{\prime}\right.$ pyridylethynyl)benzene and Mercury(II) Chloride," Journal of Chemical Crystallographyy, vol. 36, no. 9, pp. 563-566, 2006.

[31] M. M. H. Khalil, E. H. Ismail, G. G. Mohamed, E. M. Zayed, and A. Badr, "Synthesis and characterization of a novel Schiff base metal complexes and their applications in determination of iron in different types of natural water," Open Journal of Inorganic Chemistry, vol. 2, pp. 13-21, 2012.

[32] S. Chandra, S. Parmar, and Y. Kumar, "Synthesis, spectroscopic, and antimicrobial studies on bivalent zinc and mercury complexes of 2-formylpyridine thiosemicarbazone," Bioinorganic Chemistry and Applications, vol. 2009, Article ID 851316, 6 pages, 2009.

[33] T. Allen, Particle Size Measurement, Chapman \& Hall, NewYork, NY, USA, 4th edition, 1990.

[34] R. S. Joseyphus and M. S. Nair, "Antibacterial and antifungal studies on some Schiff base complexes of Zinc(II)," Mycobiology, vol. 36, no. 2, pp. 93-98, 2008.

[35] K. Dua, M. V. Ramana, U. V. Singh Sara et al., "Investigation of enhancement of solubility of norfloxacin $\beta$-cyclodextrin in presence of acidic solubilizing additives," Current Drug Delivery, vol. 4, no. 1, pp. 21-25, 2007.

[36] M. M. Hania, "Synthesis and antibacterial activity of some transition metal complexes of oxime, semicarbazone and phenylhydrazone," E-Journal of Chemistry, vol. 6, supplement 1, pp. S508S514, 2009.

[37] S. Biswas, T. Murugesan, K. Maiti, L. Ghosh, M. Pal, and B. P. Saha, "Study on the diuretic activity of Strychnos potatorum Linn. seed extract in albino rats," Phytomedicine, vol. 8, no. 6, pp. 469-471, 2001. 

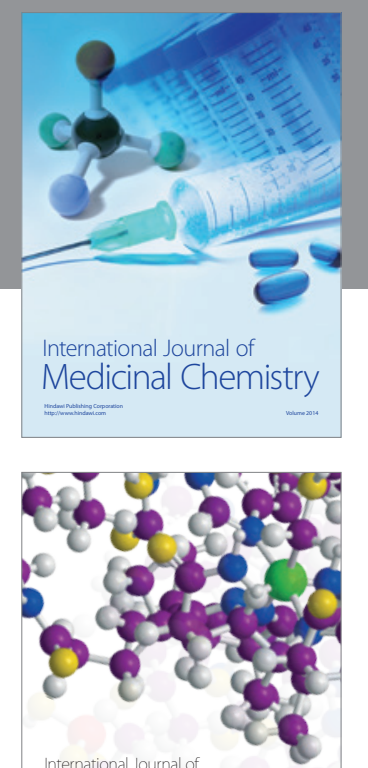

\section{Carbohydrate} Chemistry

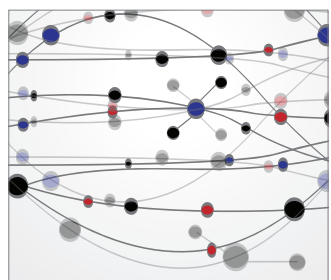

The Scientific World Journal
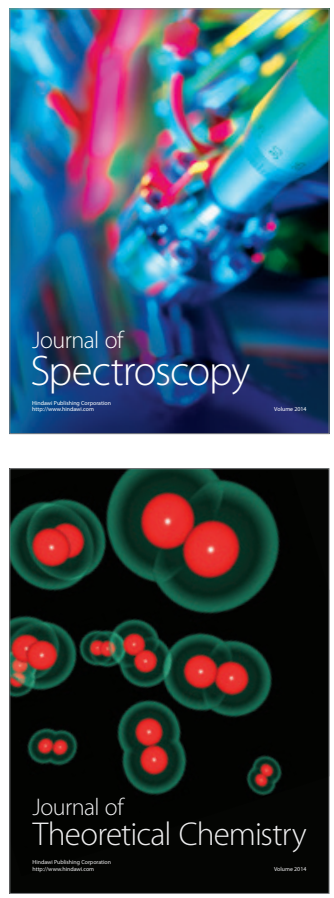
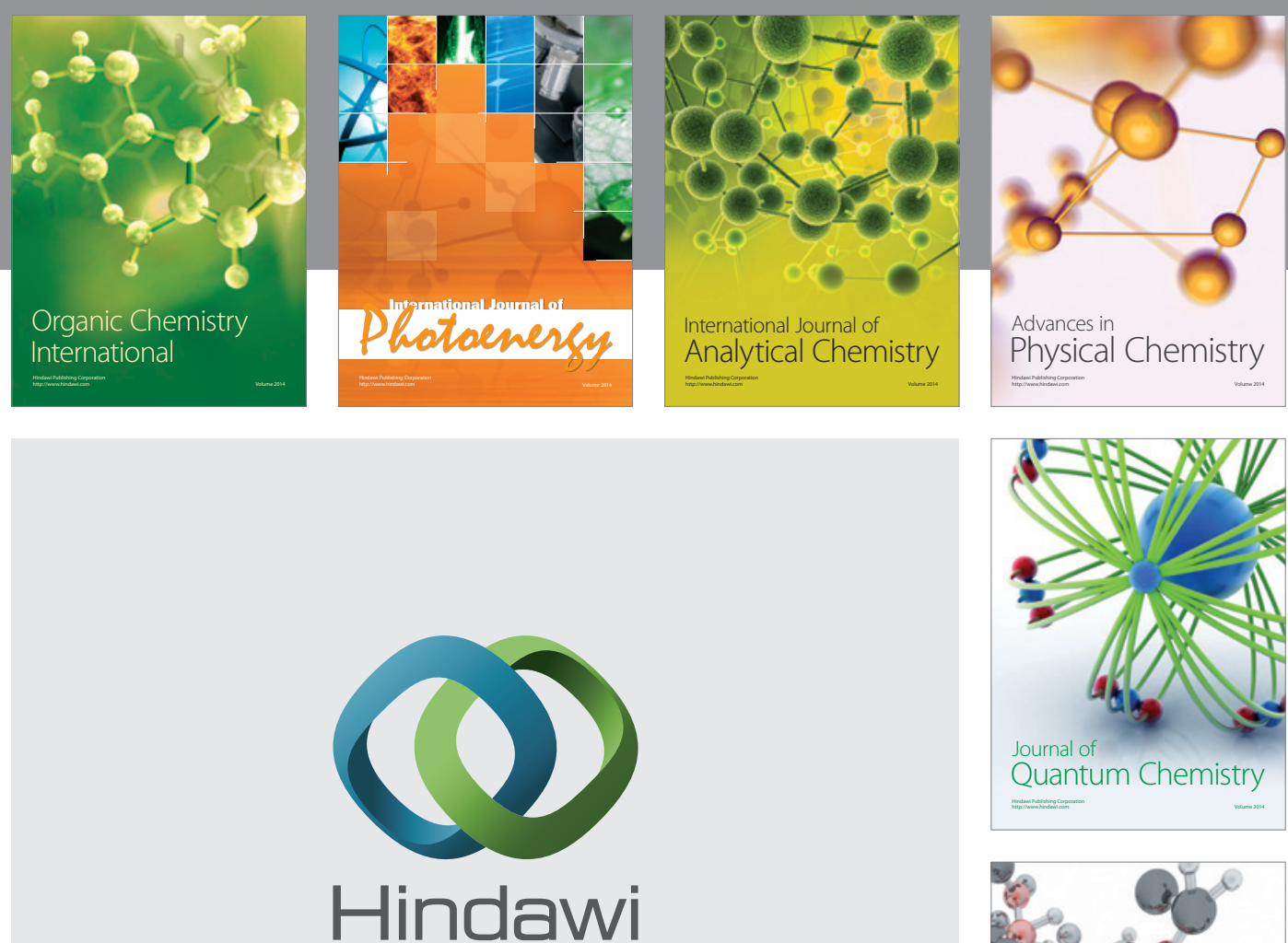

Submit your manuscripts at

http://www.hindawi.com

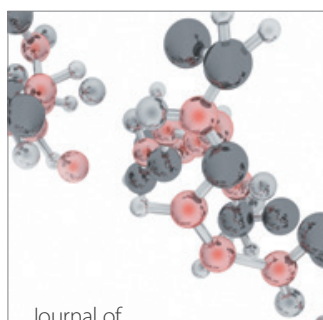

Analytical Methods

in Chemistry

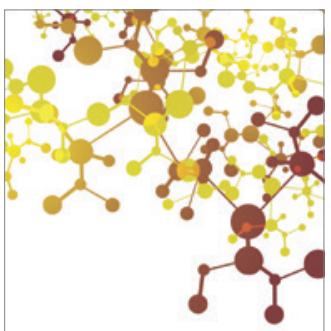

Journal of

Applied Chemistry

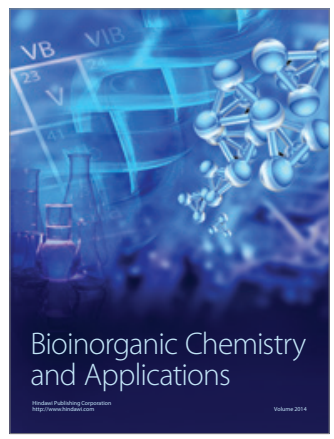

Inorganic Chemistry
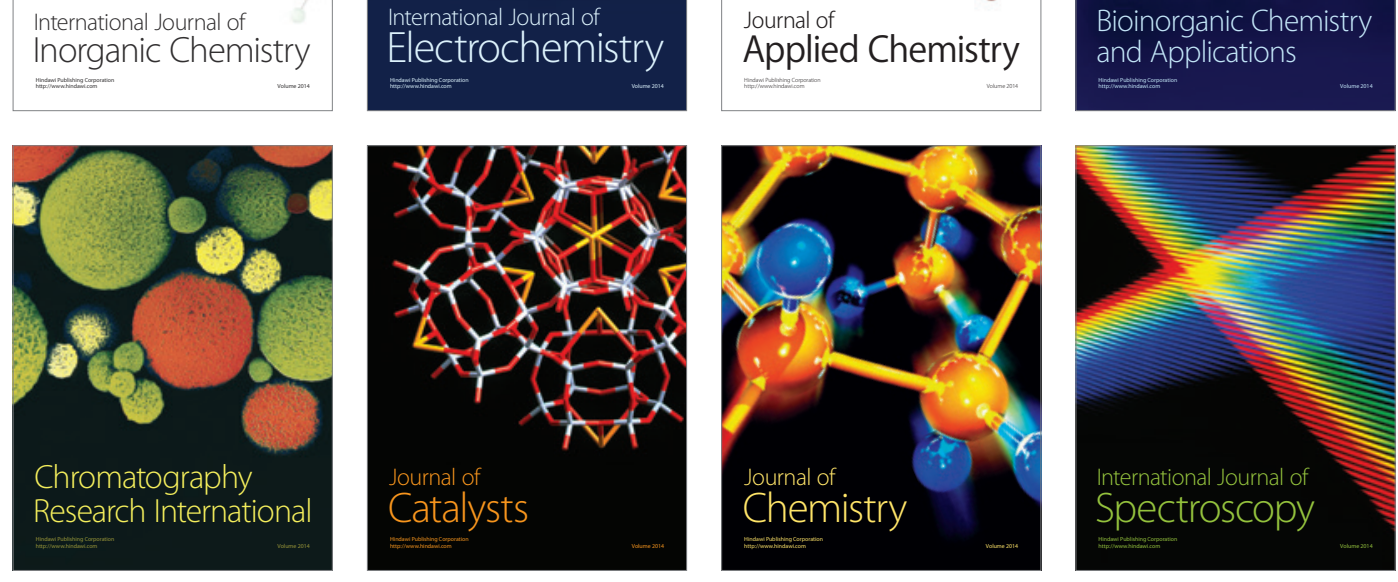